\title{
DETERMINATION OF CLEMASTINE BY THE HPLC METHOD IN THE BLOOD
}

Topicality. Clemastine fumarate (tavegil)-1-methyl-2 [2- $\alpha$-methyl-p-chlorobenzhydryloxy)-ethyl]-pyrrolidine fumarate is the first generation $\mathrm{H}_{1}$-histamine receptor blocker. Clemastine fumarate selectively inhibits histamine $\mathrm{H}_{1}$ receptors and reduces capillary permeability. The drug has a pronounced anti-allergic and antipruritic effect. Clemastine prevents the development of vasodilation and the smooth muscle contraction induced by histamine. Clemastine fumarate has an isignificant anticholinergic activity, causes sedation. The drug is used to treat pruritus in psoriasis, multiple sclerosis and optic neuritis. Clemastine is characterized by the following side effects: increased fatigue, drowsiness, sedation, weakness, lethargy, impaired coordination of movements; nausea, vomiting, decreased blood pressure, palpitations, hemolytic anemia, skin rash, anaphylactic shock. In case of an overdose, the drug has a neurotoxic effect, which manifests itself in impaired consciousness with the development of generalized anticholinergic convulsive syndrome. The urgent task for monitoring the treatment effectiveness of the population with clemastine fumarate and diagnosis of drug intoxication is the choice of highly sensitive and selective research methods of its analysis in pharmaceuticals and biological matrices during the treatment.

Aim. To develop an algorithm for directed analysis of clemastine in biological extracts from the blood using a unified method of the HPLC research.

Materials and methods. The extraction of clemastine was performed with chloroform at $\mathrm{Ph} 9.0$. The extracts were purified from impurities by a combination of TLC and extraction with hexane. The TLC purification and identification of clemastine were carried out under optimal conditions: the system of organic solvents - methanol - $25 \%$ solution of ammonium hydroxide (100: 1.5) and chromatographic plates - Sorbfil PTLC-AF-A, $R_{\text {fclemastine }}=0.60 \pm 0.03$. To detect clemastine, the most sensitive location reagents were used -UV light $(\lambda=254 \mathrm{~nm})$ and Dragendorff's reagent modified by Mounier. The chromatographic analysis was performed on a "Milichrome A-02" microcolumn liquid chromatograph (EkoNova, Closed Joint-Stock Company, Russia) under standardized HPLC conditions: the reversed-phase variant using a metal column with a non-polar absorbent Prontosil 120-5C $18 \mathrm{AQ}, 5 \mu \mathrm{m}$; the mobile phase in the linear gradient mode - from eluent A ( $5 \%$ acetonitrile and $95 \%$ buffer solution - $0.2 \mathrm{M}$ solution of lithium perchlorate in $0.005 \mathrm{M}$ solution of perchloric acid) to eluent B (100\% acetonitrile) for $40 \mathrm{~min}$. Regeneration of the column was conducted for 2 min with the mixture of solvents; the flow rate of the mobile phase was $100 \mu \mathrm{l} / \mathrm{min}$, the injection volume $-4 \mu \mathrm{l}$. The multichannel detection of the substance was performed using a two-beam multi-wave UV spectrophotometer at 8 wavelengths of $210,220,230,240,250,260,280$, and $300 \mathrm{~nm}$; the optimal value of the column temperature $-37-40^{\circ} \mathrm{C}$ and the pump pressure - 2.8-3.2 $\mathrm{MPa}$.

Results and discussion. Isolation of clemastine from the blood was performed according to the method developed, including the extraction with chloroform at $\mathrm{pH}$ 9.0; the extraction purification of extracts with hexane from impurities; the TLC purification and identification of clemastine. Using the unified HPLC method clemastine was identified by retention parameters and spectral ratios. For the quantitative determination, a calibration graph or the straight line equation corresponding to this graph were used. The results obtained indicated the reliability and reproducibility of the method. It was found that the relative uncertainty of the average result in the analysis of clemastine in the blood was $\bar{\varepsilon}= \pm 4.63 \%$, the relative standard deviation of the average result was $R S D \bar{x}=1.67 \%$.

Conclusions. Clemastine was extracted with chloroform at pH 9.0 from the blood. Purification of extracts from co-extractive compounds was performed by combining TLC and extraction with hexane. It has been found that when isolating clemastine from the blood according to the methods developed it is possible to determine $36.05-39.55 \%$ of the substance $(\bar{\varepsilon}= \pm 4.63 \%, R S D \bar{x}=1.67 \%)$. The method of TLC purification and identification of clemastine in biogenic extracts was tested under the optimal conditions: the system of organic solvents - methanol - $25 \%$ solution of ammonium hydroxide (100: 1.5$)$, the use of reagents - UV light, Dragendorff's reagent modified by Mounier, $R_{\text {fclemastine }}=0.60 \pm 0.03$ (Sorbfil PTLC-AF-A). The unified HPLC method for identification and quantification of clemastine was tested in biogenic extracts from the blood according to the algorithm of the directed analysis developed. It has been found that clemastine can be identified by the retention time - 25.997-26.011 min; the retention volume - 2599.7-2601.1 $\mu \mathrm{l}$; spectral ratios $0.741 ; 0.536 ; 0.096 ; 0.023 ; 0.027 ; 0.005 ; 0.003$. The clemastine content was determined by the equation $\mathrm{S}=0.15 \cdot 10^{-3}$ $\mathrm{C}+0.14 \cdot 10^{-3}$; the correlation coefficient was equal to 0.9998 . Chromatographic methods can be recommended for implementation in practice of the Bureau of Forensic Medical Examination, poison control centers, clinical laboratories regarding the study of medicinal substances in biological objects.

Key words: clemastine fumarate (tavegil); extraction with chloroform; purification of extracts from impurities by the TLC method and extraction with hexane; identification and quantitative determination by HPLC; blood. 


\section{О. О. Маміна, В. І. Кабачний, Н. Ю. Бондаренко, О. О. Мозгова \\ Національний фармацевтичний університет Міністерства охорони здоров'я України \\ Визначення клемастину ВEPX-методом у крові}

Актуальність. Клемастину фумарат (тавегіл) -1-метил-2 [2- - -метил-п-хлорбензгідрилоксі) етил] піролідину фумарат $€$ блокатором $\mathrm{H}_{1}$-гістамінових рецепторів першого покоління. Клемастину фумарат вибірково інгібує гістамінові $\mathrm{H}_{1}$-рецептори та зменшує проникність капілярів. Препарат має виражену протиалергічну та протисвербіжну дію. Клемастин запобігає розвитку вазодилатації та скорочення гладких м'язів, викликаних гістаміном. Клемастину фумарат має незначну антихолінергічну активність, викликає седацію. Препарат застосовують для лікування псоріазу, розсіяного склерозу та невриту зорового нерва. Для клемастину характерні побічні ефекти: підвищена стомлюваність, сонливість, седативний ефект, слабкість, млявість, порушення координації рухів; нудота, блювота, зниження артеріального тиску, серцебиття, гемолітична анемія, шкірні висипання, анафілактичний шок. За передозування препарат чинить нейротоксичну дію, що проявляється порушенням свідомості з розвитком генералізованого антихолінергічного судомного синдрому. Актуальним завданням моніторингу ефективності лікування населення клемастину фумаратом і діагностики інтоксикації ліками є вибір високочутливих і селективних методів аналізу його у фармацевтичних препаратах і біологічних матрицях під час лікування.

Метою дослідження $є$ розробка алгоритму спрямованого аналізу клемастину в біологічних екстрактах крові за допомогою уніфікованого методу дослідження ВЕРХ.

Матеріали і методи. Екстракцію клемастину проводили хлороформом за рН 9,0. Екстракти очищували від домішок комбінацією ТШХ та екстракцією гексаном. Очищення ТШХ та ідентифікацію клемастину проводили в оптимальних умовах: система органічних розчинників метанол - $25 \%$ розчин гідроксиду амонію $(100: 1,5)$ та хроматографічні пластинки Sorbfil PTLC-AF-A, $R_{f \text { клемсстину }}=0,60 \pm 0,03$. Для виявлення клемастину використовували найбільш чутливі реагенти - УФ-світло ( $\lambda=254$ нм) та реагент Драгендорфа у модифікації Муньє. Хроматографічний аналіз проводили на мікроколонковому рідинному хроматографі «Milichrome A-02» (ЕкоНова, ЗАТ, Росія) із застосуванням уніфікованих умов ВЕРХ: варіант з оберненою фазою з використанням металевої колонки з неполярним сорбентом Prontosil 120-5C 18 AQ, 5 мкм; рухома фаза в режимі лінійного градієнта - від елюента A (5 \% ацетонітрилу та 95 \% буферного розчину - 0,2 М розчину перхлорату літію в 0,005 М розчині кислоти хлорної) до елюента В (100 \% ацетонітрил) протягом 40 хв. Регенерацію колонки проводили протягом 2 хв сумішшю розчинників; швидкість потоку рухомої фази складала 100 мкл/хв, об'єм проби - 4 мкл. Багатоканальне виявлення речовини проводили за допомогою двопроменевого багатохвильового УФ-спектрофотометра за 8 довжин хвиль 210, 220, 230, 240, 250, 260, 280 і 300 нм; оптимальне значення температури колонки $-37-40^{\circ} \mathrm{C}$; тиск насоса $-2,8-3,2$ МПа.

Результати та їх обговорення. Виділення клемастину з крові проводили за розробленою методикою, яка передбачала екстракцію хлороформом за рH 9,0; екстракційне очищення екстрактів гексаном від домішок; ТШХ-очищення та ідентифікацію клемастину. За допомогою уніфікованого методу ВЕРХ клемастин ідентифікували за параметрами утримування та спектральними співвідношеннями. Для кількісного визначення використовували калібрувальний графік або рівняння прямої лінії, що відповідало цьому графіку. Отримані результати свідчили про надійність і відтворюваність методу. Було з'ясовано, що відносна невизначеність середнього результату під час аналізу клемастину в крові становила $\bar{\varepsilon}= \pm 4,63 \%$, відносне стандартне відхилення середнього результату дорівнювало $R S D \bar{x}=1,67 \%$.

Висновки. Клемастин екстрагували хлороформом за рН 9,0 з крові. Очищення екстрактів від співекстрактивних сполук проводили шляхом комбінування ТШХ та екстракції гексаном. 3'ясовано, що в разі виділення клемастину з крові за розробленими методами можна визначити $36,05-39,55 \%$ речовини $(\varepsilon= \pm 4,63 \%, R S D \bar{x}=1,67 \%)$. Метод очищення ТШХ та ідентифікації клемастину в біогенних екстрактах апробовано в оптимальних умовах: система органічних розчинників - метанол - $25 \%$ розчин амонію гідроксиду $(100: 1,5)$ за застосування реагентів - УФ-світла та реагента Драгендорфа у модифікації Муньє, $R f_{\text {клемастину }}=0,60 \pm 0,03$ (Sorbfil PTLC-AF-A). Уніфікований метод ВЕРХ для ідентифікації та кількісної оцінки клемастину було опрацьовано в біогенних екстрактах крові згідно з розробленим алгоритмом спрямованого аналізу. Виявлено, що клемастин можна ідентифікувати за часом утримування 25,997-26,011 хв; об'ємом утримування 2599,7-2601,1 мкл; спектральними співвідношеннями $-0,741 ; 0,536 ; 0,096 ; 0,023 ; 0,027 ; 0,005 ; 0,003$. Вміст клемастину визначали за рівнянням $S=0,15 \cdot 10^{-3}$ $\mathrm{C}+0,14 \cdot 10^{-3}$; коефіцієнт кореляції дорівнював 0,9998 . Хроматографічні методи можна рекомендувати для впровадження у практику бюро судово-медичної експертизи, центрів контролю за отруєннями, клінічних лабораторій щодо вивчення лікарських речовин на біологічних об'єктах.

Ключові слова: клемастину фумарат (тавегіл); екстракція хлороформом; очищення екстрактів від домішок методом ТШХ та екстракцією гексаном; ідентифікація та кількісне визначення за допомогою ВЕРХ; кров

\section{Е. А. Мамина, В. И. Кабачный, Н. Ю. Бондаренко, Е. А. Мозговая}

Национальный фармацевтический университет Министерства здравоохранения Украины

\section{Определение клемастина ВЭЖХ-методом в крови}

Актуальность. Клемастина фумарат (тавегил) -1-метил-2 [2 $\alpha$-метил-п-хлорбензгидрилокси) этил] пирролидина фумарат является блокатором $\mathrm{H}_{1}$-рецепторов первого поколения. Клемастина фумарат избирательно ингибирует гистаминовые $\mathrm{H}_{1}$-рецепторы и уменьшает проницаемость капилляров. Препарат обладает выраженным противоаллергическим и противозудным действием. Клемастин предотвращает развитие вазодилатации и сокращения гладких мышц, вызванных гистамином. Клемастина фумарат имеет незначительную антихолинергическую активность, вызывает седативный эффект. Препарат применяется для лечения псориаза, рассеянного склероза и неврита зрительного нерва. Для клемастина характерны побочные эффекты: повышенная утомляемость, сонливость, седативный эффект, слабость, вялость, нарушение координации движений; тошнота, рвота, снижение артериального давления, сердцебиение, гемолитическая анемия, кожные высыпания, анафилактический шок. При передозировке препарат оказывает нейротоксическое действие, которое проявляется в нарушении сознания с развитием генерализованного антихолинергического судорожного синдрома. Актуальной задачей мониторинга эффективности лечения населения клемастина фумаратом и диагностики лекарственной интоксикации является выбор высокочувствительных и селективных методов его анализа в фармацевтических препаратах и биологических матрицах во время лечения. 
Целью исследования является разработка алгоритма направленного анализа клемастина в биологических экстрактах крови с помощью унифицированного метода исследования ВЭЖХ.

Материалы и методы. Экстракцию клемастина проводили хлороформом при рН 9,0. Экстракты очищали от примесей комбинацией ТСХ и экстракцией гексаном. Очистка ТСХ и идентификация клемастина проводились в оптимальных условиях: система органических растворителей метанол - 25 \% раствор гидроксида аммония $(100: 1,5)$ и хроматографические пластинки Sorbfil PTLC-AF-A, $R f_{\text {клемастина }}=0,60 \pm 0,03$. Для обнаружения клемастина использовали наиболее чувствительные реагенты - УФ-свет $(\lambda=254$ нм) и реагент Драгендорфа в модификации Мунье. Хроматографический анализ проводили на микроколоночном жидкостном хроматографе «Milichrome A-02» (ЭкоНова, ЗАО, Россия) с применением унифицированных условий ВЭЖХ: вариант с обращенной фазой с использованием металлической колонки с неполярным сорбентом Prontosil 120-5C 18 AQ, 5 мкм; подвижная фаза в режиме линейного градиента - от элюента А (5 \% ацетонитрила и 95 \% буферного раствора - 0,2 М раствора перхлората лития в 0,005 М растворе кислоты хлорной) до элюента В (100\% ацетонитрил) в течение 40 мин. Регенерацию колонки проводили в течение 2 мин смесью растворителей; скорость потока подвижной фазы составляла 100 мкл/мин, объем пробы - 4 мкл. Многоканальное детектирование вещества проводили с помощью двухлучевого УФ-спектрофотометра при 8 длинах волн 210, 220, 230, 240, 250, 260, 280 и 300 нм; оптимальное значение температуры колонки - 37-40 C ; давление насоса - 2,8-3,2 МПа.

Результаты и их обсуждение. Выделение клемастина из крови проводили по разработанной методике, включая экстракцию хлороформом при рН 9,0; экстракционную очистку экстрактов гексаном от примесей; ТСХ-очистку и идентификацию клемастина. С помощью унифицированного метода ВЭЖХ клемастин идентифицировали по параметрам удерживания и спектральным соотношениям. Для количественного определения использовали калибровочный график или уравнение прямой линии, соответствующее этому графику. Полученные результаты свидетельствовали о надежности и воспроизводимость метода. Установлено, что относительная неопределенность среднего результата при анализе клемастина в крови составляла $\bar{\varepsilon}= \pm 4,63 \%$, относительное стандартное отклонение среднего результата было равным $R S \overline{\bar{x}}=1,67 \%$.

Выводы. Клемастин экстрагировали хлороформом при рН 9,0 из крови. Очистку экстрактов от соэкстрактивних веществ проводили путем комбинирования ТСХ и экстракции гексаном. Установлено, что при выделении клемастина из крови по разработанным методикам можно определить $36,05-39,55 \%$ вещества $(\bar{\varepsilon}= \pm 4,63 \%$, $R S \bar{D}=1,67$ \%). Метод очистки ТCX и идентификации клемастина в биогенных экстрактах апробирован в оптимальных условиях: система органических растворителей метанол - 25 \% раствор гидроксида аммония (100: 1,5), применение реагентов - УФ-света и реагента Драгендорфа в модификации Мунье, $R f_{\text {клемастина }}=0,60 \pm 0,03$ (Sorbfil PTLC-AF-A). Унифицированный метод ВЭЖХ для идентификации и количественной оценки клемастина был апробирован в биогенных экстрактах крови согласно разработанного алгоритма направленного анализа. Установлено, что клемастин можно идентифицировать по времени удерживания 25,997-26,011 мин; объему удерживания 2599,7-2601,1 мкл; спектральным соотношениям - 0,741; 0,536; 0,096; 0,023; 0,027; 0,005; 0,003. Содержание клемастина определяли по уравнению $\mathrm{S}=0,15 \cdot 10^{-3} \mathrm{C}+0,14 \cdot 10^{-3}$, коэффициент корреляции равен 0,9998. Хроматографические методы можно рекомендовать для внедрения в практику бюро судебно-медицинской экспертизы, центров контроля за отравлениями, клинических лабораторий по изучению лекарственных веществ на биологических объектах.

Ключевые слова: клемастина фумарат (тавегил); экстракция хлороформом; очистка экстрактов от примесей методом ТСХ и экстракцией гексаном; идентификация и количественное определение с помощью ВЭЖХ; кровь

\section{INTRODUCTION}

Clemastine fumarate (tavegil)-1-methyl-2[2- $\alpha$-methylp-chlorobenzhydryloxy)-ethyl]-pyrrolidine fumarate is the first generation $\mathrm{H}_{1}$-histamine receptor blocker. Clemastine fumarate selectively inhibits histamine $\mathrm{H}_{1}$ receptors and reduces capillary permeability. The drug has a pronounced anti-allergic and antipruritic effect, which reaches its maximum in 5-7 hours and lasts for 10-12 hours. Clemastine prevents the development of vasodilation and the smooth muscle contraction induced by histamine. The drug reduces the permeability of blood vessels, capillaries, inhibits exudation and formation of edema, reduces itching, and has the $m$-anticholinergic effect. Clemastine fumarate has an isignificant anticholinergic activity, causes sedation $[1,2]$. The drug is used to treat pruritus in psoriasis [3], multiple sclerosis [4], and optic neuritis [5].

Clemastine is characterized by the following side effects: increased fatigue, drowsiness, sedation, weakness, lethargy, impaired coordination of movements; nausea, vomiting, decreased blood pressure, palpitations, hemolytic anemia, skin rash, anaphylactic shock. In case of an overdose, the drug has a neurotoxic effect, which mani- fests itself in impaired consciousness with the development of generalized anticholinergic convulsive syndrome [6, 7].

The urgent task for monitoring the treatment effectiveness of the population with clemastine fumarate and diagnosis of drug intoxication is the choice of highly sensitive and selective research methods of its analysis in pharmaceuticals and biological matrices during the treatment.

According to the toxicological studies, one of the leading places among drug poisonings is occupied by intoxication with antihistamines due to the multi-vector pharmacological effects, the uncontrolled use of many combined drugs for the treatment of seasonal diseases. According to the literature, systematic studies of most antihistamines of the first generation are absent, the methods of their isolation, identification, quantification in biological objects have been insufficiently studied. All these determines the relevance of such studies using modern highly sensitive and selective methods of analysis [6, 7].

The development of the analytical service in the directions of monitoring the treatment effectiveness of the population with antihistamines and diagnosis of intoxications with the use of these drugs is based on the creation 
of databases of effective, economical and express methods of the drug analysis in biological objects using a unified HPLC method [8, 9].

Clemastine is determined in drugs and biological objects by such highly sensitive methods as spectrophotometry [10], thin layer chromatography (TLC) [11, 12], high performance liquid chromatography (HPLC) $[9,13,14]$.

The most common highly sensitive and selective chromatographic methods of chemical and toxicological analysis of the first-generation antihistamines are HPLC and TLC. These methods are widely used for the separation of drug mixtures, detection of impurities and purification from them.

The literature presents HPLC methods for the study of clemastine using different conditions (variants for detecting the test substance, the use of isocratic and gradient modes of elution, the use of different compositions of mobile phases, sorbents, buffer solutions).

According to the European Pharmacopoeia, the HPLC analysis of the methanol solution of clemastine was performed using the reversed-phase chromatography with an UV-detector. Detection of substances was carried out at a wavelength of $220 \mathrm{~nm}$; the column $(0.1 \mathrm{~m} \times 4.6 \mathrm{~mm})$ with octadecyl silica gel C18, $5 \mu \mathrm{m}$. The mobile phase was orthophosphoric acid - acetone - $1 \%$ solution of ammonium dihydrophosphate $(0.1: 45: 55)$. The flow rate of the eluent in the column was $1.0 \mathrm{ml} / \mathrm{min}$ [13].

For HPLC separation of antihistamines, the use of different conditions is recommended: the column: $\mathrm{C}_{18}$ endcapped LiChrospher $100 \mathrm{RP}-18,(125 \times 4.0 \mathrm{~mm}, 5 \mu \mathrm{m})$ with the pre-column LiChrocart; the mobile phase: addition of $146 \mu \mathrm{l}$ of triethylamine and about $750 \mu \mathrm{l}$ of phosphoric acid to $530 \mathrm{ml}$ of water. The $\mathrm{pH}$ was adjusted to 3.3 using $10 \%$ potassium hydroxide solution, then $470 \mathrm{ml}$ acetonitrile was added. The flow rate was $0.6 \mathrm{ml} / \mathrm{min}$; detection - UV diode-array; the retention time of clemastine - $14 \min [9]$.

The disadvantages of the above HPLC methods are the use of isocratic elution regime $[9,13]$, which limits the possibility of all sample components leaving the column in the form of narrow zones and effective separation of drug mixtures. Detection at the same wavelength [13] reduces the reliability of the results obtained in the identification and study of mixtures with other drugs since it allows using only the retention parameters without the use of spectral ratios.

Modern HPLC methods for the analysis of clemastine indicate the absence of systematic studies, which does not allow the selection of the optimal conditions for the analysis of the drug in biological objects and pharmaceuticals.

The aim of the study is to develop an algorithm for directed analysis of clemastine in biological extracts from the blood using a unified method of the HPLC research.

To achieve these aims, the following tasks should be solved:

1. to carry out extraction of clemastine according to the method developed for isolation of organic substances of the basic character from biological objects;
2. to select the optimal conditions for TLC purification and identification of clemastine in biogenic extracts (thin layers of sorbents, organic solvent systems, substance detection agent);

3. to approve a unified HPLC method for identification and quantification of clemastine in biogenic extracts from the blood according to the algorithm of directed analysis developed in biological extracts using a unified HPLC method.

\section{MATERIALS AND METHODS}

Clemastine fumarate (tavegil) was isolated from "Tavegil" tablets (10 pcs), $1 \mathrm{mg}$ (Novartis AG, pharmaceutical company, Basel, Switzerland) as follows: the number of tablets containing $200 \mathrm{mg}$ was transferred to a porcelain mortar and triturated to a homogeneous state. $100.0 \mathrm{ml}$ of methanol was added to the mixture and mixed thoroughly. The resulting mixture was filtered through a paper filter in a porcelain cup and evaporated on a water bath at a temperature not higher than $40^{\circ} \mathrm{C}$ to remove the organic solvent; the residue was dried.

$0.1000 \mathrm{~g}$ of the test substance was added to a $100.0 \mathrm{ml}$ volumetric flask, dissolved in methanol, and the solution was diluted to the volume with the solvent (the standard solution with the concentration of $1000.0 \mu \mathrm{g} / \mathrm{ml}$ ).

Organic solvents - chloroform, methanol, hexane were of analytical grade (Sigma-Aldrich, USA). Reagents $10 \%$ solution of trichloroacetic acid, $25 \%$ solution of ammonium hydroxide, $0.1 \mathrm{M}$ solution of sodium hydroxidewere also of analytical grade (Chimmed, Russia).

According to the algorithm for the study of biological objects for the presence of drugs, the following steps were performed: isolation of the substance from the biological object, purification from nutrients, identification and quantification. Purification of extracts from co-extractive compounds was performed by combining TLC and hexane extraction $[16,17]$.

A model mixture of the blood with clemastine fumarate was used for the research. To $10 \mathrm{ml}$ of the appropriate biological fluid, $1000.0 \mu \mathrm{g}$ of clemastine fumarate using the methanol solution of the drug substance containing $1000.0 \mu \mathrm{g} / \mathrm{ml}$, as well as control samples, were added. The samples were left for $24 \mathrm{~h}$ at room temperature. A day later, the studies were performed according to the extraction procedures developed.

Methods of isolation of clemastine from the blood and extraction purification by hexane. To $10.0 \mathrm{ml}$ of a model mixture of the blood with clemastine fumarate, $5.0 \mathrm{ml}$ of $10 \%$ solution of trichloroacetic acid was added for breaking bonds with proteins, mixed and checked with an universal indicator of the mixture $\mathrm{pH}$ of $2.0-2.5$, allowed to stand for $2 \mathrm{~h}$ with constant stirring at room temperature.

The mixture was centrifuged at 3000-5000 rpm for $10 \mathrm{~min}$, the liquid over the precipitate was separated. Lipid impurities were extracted three times with hexane in portions of $5 \mathrm{ml}$. The hexane phases were not studied.

The aqueous layer was alkalinized with $0.1 \mathrm{M}$ solution of sodium hydroxide to $\mathrm{pH} 9.0$, and the clemastine 
base was extracted twice with chloroform in portions of $10.0 \mathrm{ml}$ followed by centrifugation at 3000-5000 rpm for $10 \mathrm{~min}$ to destruct water-chloroform emulsions. Chloroform extracts were combined and filtered through a paper filter ("red tape") with $1.0 \mathrm{~g}$ of anhydrous sodium sulphate, and TLC-purification of the extracts was performed.

Methods of TLC purification of biogenic extracts. The purified chloroform solutions were evaporated at room temperature to dryness, dissolved in $2.0-3.0 \mathrm{ml}$ of methanol, then quantitatively transferred to a $5.0 \mathrm{ml}$ volumetric flask, and diluted to the volume with methanol.

The TLC purification and identification of clemastine were performed under conditions: chromatographic plates Sorbfil PTLC-AF-A, the system of organic solvents - methanol - $25 \%$ solution of ammonium hydroxide (100: 1.5 ), $R_{\text {fclemastine }}=0.60 \pm 0.03$, impurities were located at the start line or at the finish line. The detection of clemastine was performed under uniform conditions using the most sensitive developers: UV light $(\lambda=254 \mathrm{~nm})$ - a purple color of spots, sensitivity in the sample - 0.3-0.5 $\mu \mathrm{g}$, Dragendorff's reagent modified by Mounier - an orange color of spots, sensitivity of the developer - 1.0-3.0 $\mu \mathrm{g}$ of the substance in the sample [12].

The TLC purification of clemastine in the extracts was performed according to the following method: $1.0 \mathrm{ml}$ of the methanol solution of clemastine after extraction purification was evaporated to 0.3-0.5 $\mathrm{ml}$. At the starting line of the chromatographic plate at a distance of $1-2 \mathrm{~cm}$ from the edge to the point, $0.01 \%$ methanol solution of clemastine was applied using a calibrated capillary witness. At a distance of 1-2 cm from the witness, the extract from the control sample was applied, the diameter of the stain should not exceed $0.5 \mathrm{~cm}$. The methanol solution of clemastine after extraction purification was applied in the form of a strip of 1.0-1.5 cm long.

The chromatographic plate was placed in a chromatography chamber, which was a glass vessel with a ground lid with a volume of $500 \mathrm{~cm}^{3}$; the system of solvents for chromatography ( $50 \mathrm{ml}$ ) was introduced into it. The chamber was carefully closed, and there was the solvent vapor saturation for at least 30-60 min. The length of the mobile phase front was $7 \mathrm{~cm}$. The chromatography was completed when the solvent reached the finish line. The chromatographic plate was dried at room temperature, after that its part with spots of the witness and extracts from the control sample was developed using UV light and Dragendorff's reagent modified by Mounier.

At the level of the spot of the standard methanol, $0.01 \%$ solution of clemastine from the part of the plate that was not treated with the developer removed a layer of the sorbent with an area of $4-5 \mathrm{~cm}^{2}$, and was transferred to the filter. The substance was eluted three times with $5.0 \mathrm{ml}$ of methanol, and the resulting solution was filtered through a filter ("red tape").

The resulting solutions were evaporated at room temperature to dryness, dissolved in $2.0-3.0 \mathrm{ml}$ of methanol, and then quantitatively transferred to a $5.0 \mathrm{ml}$ volumetric flask, and diluted to the volume with methanol.

Methods of studying clemastine by HPLC. The chromatographic analysis was performed on a "Milichrome A-02" microcolumn liquid chromatograph (EkoNova, Closed JointStock Company, Russia) according to the unified HPLC method developed by Baram G.Y. [14]: the reversed-phase variant using a metal column with a non-polar absorbent Prontosil 120-5C 18 AQ, $5 \mu \mathrm{m}$; the mobile phase in the linear gradient mode - from eluent A ( $5 \%$ acetonitrile and $95 \%$ buffer solution - 0.2 M solution of lithium perchlorate in $0.005 \mathrm{M}$ solution of perchloric acid) to eluent $\mathrm{B}$ (100\% acetonitrile) for $40 \mathrm{~min}$. Regeneration of the column was conducted for 2 min with the mixture of solvents; the flow rate of the mobile phase was $100 \mu \mathrm{l} / \mathrm{min}$, the injection volume $-4 \mu$ l.

The multichannel detection of the substance was performed using a two-beam multi-wave UV spectrophotometer at 8 wavelengths of $210,220,230,240,250,260$, 280 , and $300 \mathrm{~nm}$; the optimal value of the column temperature $-37-40^{\circ} \mathrm{C}$ and the pump pressure $-2.8-3.2 \mathrm{MPa}$.

\section{RESULTS AND DISCUSSION}

Identification of clemastine was performed by retention parameters and spectral ratios. It was found that the absolute retention time of clemastine was 25.997-26.011 min, and the absolute retention volume was 2599.7-2601.1 $\mu \mathrm{l}$.

To obtain reliable identification results, the spectral ratios of the optical density values at wavelengths from 220 to $280 \mathrm{~nm}$ to the optical density values at $210 \mathrm{~nm}$ were determined $-0.741 \pm 0.005 ; 0.536 \pm 0,005 ; 0.096 \pm 0.006$; $0.023 \pm 0.006 ; 0.027 \pm 0.006 ; 0.005 \pm 0.005 ; 0.003 \pm 0.008$.

Peak symmetry coefficients and capacitance coefficients were determined to verify the choice of chromatography conditions. It was found that the values of the coefficients of symmetry of the peaks were equal to $0.92 \pm 0.07$ (less than 2.0-2.5), and the coefficients of capacity $16.34 \pm 0.02$ (more than $0.5-2.0$ ) showed the suitability of the chromatographic system HPLC analysis [15].

The method of the clemastine determination by HPLC was validated by the following parameters: the range of linearity, limits of the quantitative determination (LOQ), accuracy and precision in the areas of low, medium and high concentrations of the test substance [18]. To quantify clemastine, the absolute calibration method was applied using the area of the peaks of the substances.

The concentration of clemastine in the methanol solution (C, $\mu \mathrm{g} / \mathrm{ml}$ ) obtained after purification of biogenic extracts by TLC and extraction methods was calculated using a calibration graph or the equation of the line corresponding to the calibration graph.

The linearity of the calibration graph was observed in the concentration ranges of 5.0-100.0 $\mu \mathrm{g} / \mathrm{ml}$, which corresponded to the content of clemastine in the sample $(4 \mu \mathrm{l})$ from $20.0 \mathrm{ng}$ to $400.0 \mathrm{ng}$. The lower limit of the clemastine determination by HPLC was $5.0 \mu \mathrm{g} / \mathrm{ml}(20.0 \mathrm{ng}$ in the sample). 
THE RESULTS OF THE HPLC ANALYSIS OF CLEMASTINE EXTRACTS IN THE BLOOD ( $\mathrm{n}=\mathbf{5}, \mathrm{P}=95 \%$ )

\begin{tabular}{|c|c|c|c|c|c|c|c|c|}
\hline \multirow{2}{*}{$\begin{array}{l}\text { The value of the area } \\
\text { of the peaks, } \mathrm{S}, \mathrm{mm}^{2}\end{array}$} & \multicolumn{2}{|c|}{ The clemastine isolated } & \multicolumn{6}{|c|}{ Metrological characteristics, $\%$} \\
\hline & $\mu \mathrm{g}$ & $\%$ & $\bar{X}$ & S & $R S D \bar{x}$ & $\mathrm{~S}_{\bar{x}}$ & $\Delta \bar{x}$ & $\bar{\varepsilon}$ \\
\hline 0.00186 & 11.46 & 38.4 & & & & & & \\
\hline 0.00176 & 10.81 & 36.2 & 37.8 & 1.41 & 1.67 & 0.63 & 1.75 & 4.63 \\
\hline 0.00179 & 10.99 & 36.8 & & & & & & \\
\hline 0.00192 & 11.88 & 39.8 & & & & & & \\
\hline
\end{tabular}

THE ALGORITHM FOR THE DIRECTED ANALYSIS OF CLEMASTINE IN THE BLOOD

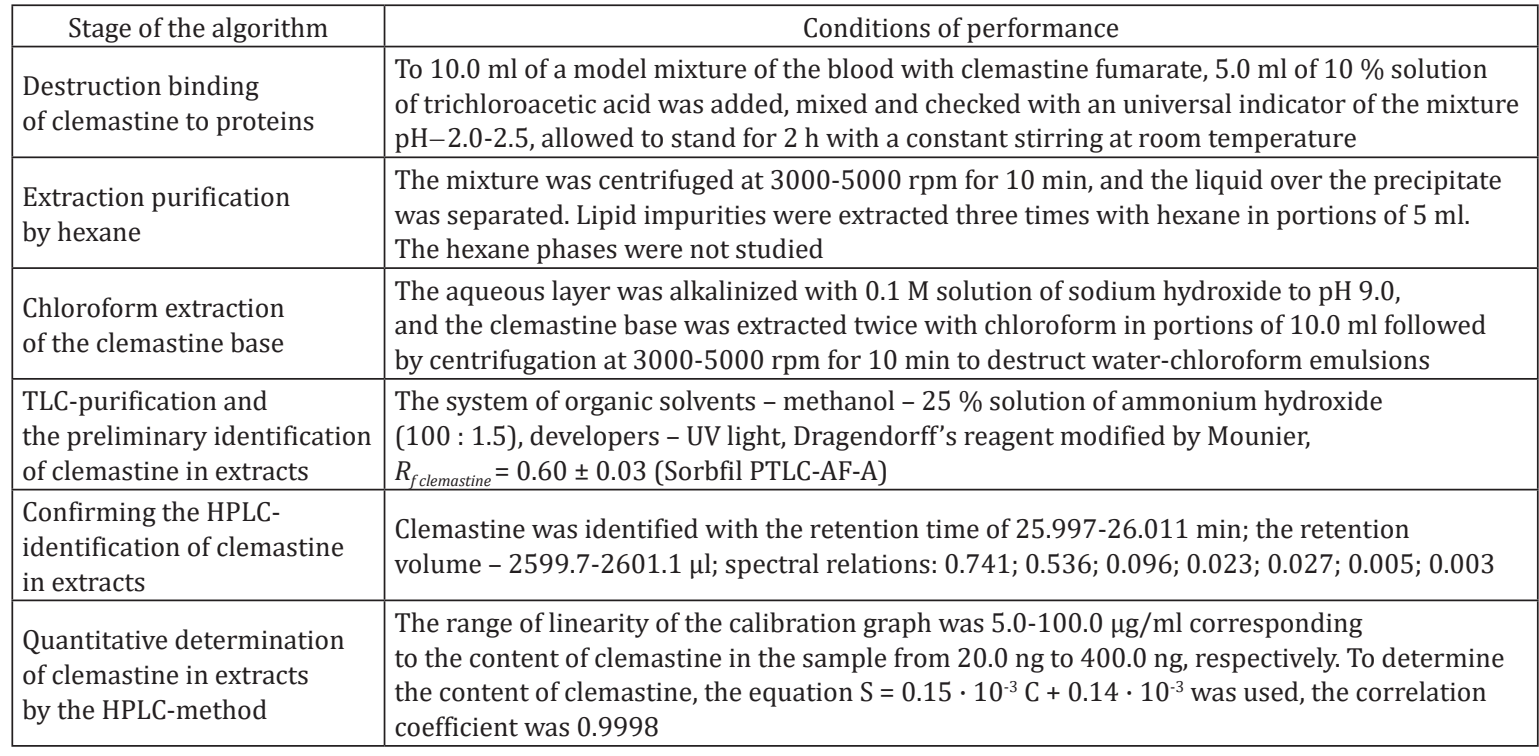

The equation of the linear dependence of the area of clemastine peaks $\left(\mathrm{S}, \mathrm{mm}^{2}\right)$ on its concentration $(\mathrm{C}, \mu \mathrm{g} / \mathrm{ml})$ had the form of $\mathrm{S}=0.15 \cdot 10^{-3} \mathrm{C}+0.14 \cdot 10^{-3}$. The correlation coefficient was 0.9998 [18].

When performing the HPLC analysis of clemastine in model solutions using the method proposed the relative uncertainty of the average results did not exceed $\pm 1.90 \%$, indicating the suitability of HPLC conditions for analysis in biological objects.

The amount of clemastine in the blood samples was calculated by the formula:

$$
\mathrm{C}_{\mathrm{x}}=\frac{\mathrm{C} \cdot \mathrm{V}_{1} \cdot \mathrm{V}_{3} \cdot \mathrm{k} \cdot 100}{\mathrm{a} \cdot \mathrm{V}_{2}}
$$

where: $\mathrm{C}_{\mathrm{x}} \%$ - is the mass fraction of clemastine in $10 \mathrm{ml}$ of the blood, \%; $\mathrm{V}_{1}$ - is the volume of a volumetric flask with the methanol extract of the substance from the blood after extraction purification, $5 \mathrm{ml} ; \mathrm{V}_{2}$ - is the volume of the methanol extract of the substance from the blood taken for TLC purification, $1 \mathrm{ml} ; \mathrm{V}_{3}$ - is the volume of the volumetric flask with the extract after TLC purification using methanol, $5 \mathrm{ml} ; \mathrm{k}$ - is the coefficient of recount equal to the ratio of molecular weights of salt/base; $\mathrm{a}$ - is the weight of the sample of clemastine fumarate in $10.0 \mathrm{ml}$ of the blood, $1000.0 \mu \mathrm{g}$.
The results of the study are shown in Tab. 1.

According to the results of research, it has been found that when isolating clemastine from the blood according to the methods developed it is possible to determine $36.05-39.55 \%$ of the substance ( $= \pm 4.63 \%, R S D=1.67 \%$ ).

According to the results of HPLC and TLC studies, an algorithm for the directed blood analysis for clemastine was developed (Tab. 2).

The algorithm developed as a result of the present research had a number of advantages. They were:

- the use of a unified HPLC method made it possible to identify clemastine by retention parameters and spectral ratios, which made the results accurate, reliable and reproducible;

- the use of the linear gradient mode of clemastine elution allowed to obtain symmetrical, sharp chromatographic peaks (the peak symmetry coefficient did not exceed 2-2,5) and perform their reliable processing. The results of the identification and quantification by HPLC were calculated using a "Multichrome" computer program (CJSC "Ampersend", Russia) included in the chromatograph;

- a high degree of purification of extracts from impurities allowed to obtain reliable and reproducible results in accordance with metrological characteristics. 
The disadvantage of the analysis algorithm developed was the low degree of clemastine extraction from the blood $36.05-39.55 \%$ of the substance. These results were due to losses in the multi-stage purification of extracts from impurities. Another drawback was the use of a unified method of extraction of the substance without taking into account the individual properties of clemastine.

\section{CONCLUSIONS}

1. Clemastine was extracted with chloroform at $\mathrm{pH} 9.0$ from the blood. Purification of extracts from co-extractive compounds was performed by combining TLC and extraction with hexane. It has been found that when isolating clemastine from the blood according to the methods developed it is possible to determine $36.05-39.55 \%$ of the substance $(\bar{\varepsilon}= \pm 4.63 \%$, $R S D \bar{x}=1.67 \%$ ).

2. The method of TLC purification and identification of clemastine in biogenic extracts was tested under the optimal conditions: the system of organic solvents methanol - $25 \%$ solution of ammonium hydroxide
(100 : 1.5), the use of reagents - UV light, Dragendorff's reagent modified by Mounier, $R_{\text {fclemastine }}=0.60 \pm 0.03$ (Sorbfil PTLC-AF-A).

3. The unified HPLC method for identification and quantification of clemastine was tested in biogenic extracts from the blood according to the algorithm of directed analysis developed. It has been found that clemastine can be identified by the retention time - 25.997-26.011 min; the retention volume 2599.7-2601.1 $\mu \mathrm{l}$; spectral ratios $-0.741 ; 0.536 ; 0.096$; $0.023 ; 0.027 ; 0.005 ; 0.003$. The clemastine content was determined by the equation $\mathrm{S}=0.15 \cdot 10^{-3}$ $\mathrm{C}+0.14 \cdot 10^{-3}$; the correlation coefficient was equal to 0.9998 .

4. Chromatographic methods can be recommended for implementation in practice of the Bureau of Forensic Medical Examination, poison control centers, clinical laboratories regarding the study of medicinal substances in biological objects.

Conflict of Interests: authors have no conflict of interests to declare.

\section{REFERENCES}

1. Машковский М. Д. Лекарственные средства : пособие. 16-е изд., перераб., испр. и доп. Москва : Новая Волна, 2012.216 с.

2. Tiligada E., Ennis M. Histamine pharmacology: from Sir Henry Dale to the 21st century. British Journal of Pharmacology. 2020. Vol. 177 , Iss. 3. P. 469-489. DOI: https://doi.org/10.1111/bph.14524.

3. Domagała A., Szepietowski J., Reich A. Antihistamines in the treatment of pruritus in psoriasis. Advances in Dermatology and Allergology/Postępy Dermatologii i Alergologii. 2017. Vol. 34, № 5. P. 457-463. DOI: https://doi.org/10.5114/ada.2017.71112.

4. Clemastine fumarate as a remyelinating therapy for multiple sclerosis (ReBUILD): a randomised, controlled, double-blind, crossover trial / A. J. Green et al. The Lancet. 2017. Vol. 390, № 10111. P. 2481-2489. DOI: https://doi.org/10.1016/S0140-6736(17)32346-2.

5. Randomized control trial of evaluation of Clemastine effects on visual evoked potential, nerve fiber layer and ganglion cell layer complex in patients with optic neuritis / M. Moghaddasi et al. Clinical Neurology and Neurosurgery. 2020. Vol. 193. P. 105741. D0I: https://doi.org/10.1016/j. clineuro.2020.105741.

6. Токсические эффекты блокаторов $\mathrm{H}_{1}$ - гистаминовых рецепторов и механизмы их формирования / С. М. Дроговоз и др. Современные проблемы токсикологии. 2012. № 3-4. С. 58-59.

7. Thomas S. H. L. Antihistamine poisoning. Medicine. 2012. Vol. 40, Iss. 3. P. 109-110. DOI: https://doi.org/10.1016/j.mpmed.2011.12.012.

8. ВЭЖХ и СВЭЖХ как методы для определения лекарственных веществ в крови (обзор) / Ю. В. Медведев и др. Химико-фармацевтический журнал. 2013. Т. 47, № 4. C. 45-51. DOI: https://doi.org/10.30906/0023-1134-2013-47-4-45-51.

9. Clarke E. J. C. Isolation and Identification of Drugs in Pharmaceuticals, Body Fluids and Postmortem Material. London : The Pharm. Press, 2011.2463 p.

10. Зинин Н. Н., Кузнецова О. С., Дорофеев В. Л. УФ-спектрофотометрия: анализ препаратов $\mathrm{H}_{1}-$-гистаминовых блокаторов. Фармация. 2011. № 6. C. 9-12.

11. Czerwińska K., Wyszomirska E., Mazurek A. Identification and determination of selected histamine antagonists by densitometric method. Acta Poloniae Pharmaceutica. Drug Research. 2013. Vol. 70, №. 1. P. 19-26.

12. Prudnikova O. G., Mamina O. O., Tomarovska T. O. The choice of optimal conditions for chemical-toxicological analysis of clemastine by thin-layer chromatography. Topical issues of new medicines development : матеріали XXVI Міжнар. наук.-практ. конф. молодих учених та студентів, м. Харків, 10-12 квіт. 2019 р. Харків : НФаУ, 2019. С. 97-98.

13. European Pharmacopoeia. 6-th ed. Strasbourg: European Directorate for the Quality of Medicines \& HealthCare (EDQM), 2008. Vol. 2. P. 1566-1567.

14. Mamina O. O. Chromatographic investigation of clemastine fumarate. Фармація XXI століття: тенденції та перспективи : тези VIII Нац. з'їзду фармацевтів України, м. Харків, 13-16 верес. 2016 р. Харків, 2016. Т. 1. С. 220.

15. Meyer V. R. Practical High-Performance Liquid Chromatography. 5-th ed. New York : Wiley-VCH, 2010. 426 p.

16. Prabu S. L., Suriyaprakash T. N. K. Extraction of Drug from the Biological Matrix : a review. Applied Biological Engineering : Principles and Practice. 2012. P. 479-506. DOI: https://doi.org/10.5772/32455.

17. Рейхарт Д. В., Чистяков В. В. Анализ лекарственных средств при фармакокинетических исследованиях (обзор). Казанский медицинский журнал. 2010. Т. 91, № 4. С. 532-536.

18. Bioanalytical Method Validation : Guidance for Industry / U. S. Department of Health and Human Services, Food and Drug Administration, Center for Drug Evaluation and Research (CDER), Center for Veterinary Medicine (CVM). Biopharmaceutics, 2018. 44 p. URL: https://www.fda.gov/ downloads/drugs/guidances/ucm368107.pdf.

\section{REFERENCES}

1. Mashkovskii, M. D. (2012). Lekarstvennye sredstva. Moscow: Novaia Volna, 1216

2. Tiligada, E., Ennis, M. (2020). Histamine pharmacology: from Sir Henry Dale to the 21st century. British Journal of Pharmacology, 177, 469-489. doi: $10.1111 /$ bph.14524.

3. Domagała, A., Szepietowski, J., Reich, A. (2017). Antihistamines in the treatment of pruritus in psoriasis. Postepy Dermatologii i Alergologii, 34 (5), 457-463. doi: 10.5114/ada.2017.71112.

4. Green, A. J., Gelfand, J. M., Cree, B. A., Bevan, C., Boscardin, W. J., Mei, F., Inman, J., Arnow, S., Devereux, M., Abounasr, A. (2017). Clemastine fumarate as a remyelinating therapy for multiple sclerosis (ReBUILD): a randomised, controlled, double-blind, crossover trial. The Lancet Journal, 390 (10111), 2481-2489. doi: 10.1016/S0140-6736(17)32346-2. 
5. Moghaddasi, M., Nabovvati, M., Koushki, A., Soltansanjari, M., Sardarinia, M., Mohebi, N., Rabani, S. (2020). Randomized control trial of evaluation of Clemastine effects on visual evoked potential, nerve fiber layer and ganglion cell layer complex in patients with optic neuritis. Clinical Neurology and Neurosurgery, 193, 105741. doi: 10.1016/j.clineuro.2020.105741.

6. Drogovoz, S. M., Luk'yanchuk, V. D., Sherman, B. S., Kononenko, A. V. (2012). Sovremennye problemy toksikolohii, 3-4, 58-59.

7. Thomas, S. H. L. ( 2012). Antihistamine poisoning. Medicine, 40 (3), 109-110. doi: https://doi.org/10.1016/j.mpmed.2011.12.012.

8. Medvedev, Yu. V., Ramenskaya, G. V., Shokhin, I. Ye., Yarushok, T. A. (2013). Khimiko-farmatsevticheskii zhurnal, 47 (4), 45-51. doi: https://doi. org/10.30906/0023-1134-2013-47-4-45-51.

9. Clarke, E. J. C. (2011). Isolation and Identification of Drugs in Pharmaceuticals, Body Fluids and Postmortem Materia. London: The Pharm. Press, 2463.

10. Zinin, N. N., Kuznetsova, O. S., Dorofeev, V. L. (2011). UF-spektrofotometriya: analiz preparatov $\mathrm{N}_{1}$ - gistaminovykh blokatorov. Farmatsiia, 6, 9-12

11. Czerwińska, K., Wyszomirska, E., Mazurek, A. (2013). Identification and determination of selected histamine antagonists by densitometric method. Acta Poloniae Pharmaceutica, 70 (1), 19-26.

12. Prudnikova, O. G., Mamina, O. O., Tomarovska, T. O. (2019). The choice of optimal conditions for chemical-toxicological analysis of clemastine by thin-layer chromatography. Proceeding from Topical issues of new medicines development: XXVI International Scientific And Practical Conference of Young Scientists and Students (April 10-12, 2019). (Vols. 1-2. Vol. 1). (pp. 97-98). Kharkiv.

13. European Directorate for the Quality of Medicines \& HealthCare. (2008). European Pharmacopoeia. 6th ed. (Vol. 2). Strasbourg, France, 1566-1567.

14. Mamina, O. O. (2016). Chromatographic investigation of clemastine fumarate. Proceeding from Farmatsiia XXI stolittia: tendentsii ta perspektyvy: tezy dopovidei VIII Natsionalnoho zizdu farmatsevtiv Ukrainy (13-16 veresnia 2016 r.). (Vols. 1-2. Vol. 1). (pp. 220). Kharkiv.

15. Meyer, V. R. (2010). Practical High-Performance Liquid Chromatography. $5^{\text {th }}$ ed. New York : Wiley-VCH, 426.

16. Prabu, S. L., Suriyaprakash, T. N. K. (2012). Extraction of Drug from the Biological Matrix : a review. Applied Biological Engineering: Principles and Practice, 479-506. doi: 10.5772/32455.

17. Reykhart, D. V., Chistyakov, B. B. (2010). Kazanskii meditsinskii zhurnal, 91 (4), 532-536.

18. U.S. Department of Health and Human Services, Food and Drug Administration, Center for Drug Evaluation and Research (CDER), Center for Veterinary Medicine (CVM). (2018). Bioanalytical Method Validation: Guidance for Industry. Available at: https://www.fda.gov/downloads/drugs/guidances/ ucm368107.pdf.

\section{Information about the authors:}

Mamina O., Doctor of Pharmacy (Dr. habil.), professor of the Department of Inorganic and Physical Chemistry, National University of Pharmacy of the Ministry of Health of Ukraine. E-mail: a_mamina@ukr.net. ORCID: http://orcid.org/0000-0001-6673-1488

Kabachny V., Doctor of Pharmacy (Dr. habil.), professor of the Department of Inorganic and Physical Chemistry, National University of Pharmacy of the Ministry of Health of Ukraine. E-mail: vikpharm@gmail.com. ORCID: http://orcid.org/0000-0001-8620-2225

Bondarenko N., Candidate of Pharmacy (Ph.D.), associate professor of the Department of Inorganic and Physical Chemistry, National University of Pharmacy of the Ministry of Health of Ukraine. E-mail: tropikana@ ukr.net. ORCID: https://orcid.org/0000-0003-0620-2255

Mozgova O., Candidate of Pharmacy (Ph.D.), associate professor of the Department of Inorganic and Physical Chemistry, National University of Pharmacy of the Ministry of Health of Ukraine. E-mail: elena.mozgovaya25@gmail.com. ORCID: https://orcid.org/0000-0002-6460-6816 Відомості про авторів:

Маміна О. О., докторка фарм. наук, професорка кафедри неорганічної та фізичної хімії, Національний фармацевтичний університет Міністерства охорони здоров'я України. E-mail: a_mamina@ukr.net. ORCID: http://orcid.org/0000-0001-6673-1488

Кабачний В. І. доктор фарм. наук, професор кафедри неорганічної та фізичної хімії, Національний фармацевтичний університет Міністерства охорони здоров'я України. E-mail: vikpharm@gmail.com. ORCID: http://orcid.org/0000-0001-8620-2225

Бондаренко Н. Ю., кандидатка фарм. наук, доцентка кафедри неорганічної та фізичної хімії, Національний фармацевтичний університет Міністерства охорони здоров'я України. E-mail: tropikana@ ukr.net. ORCID: https://orcid.org/0000-0003-0620-2255 Мозгова О. О., кандидатка фарм. наук, доцентка кафедри неорганічної та фізичної хімії, Національний фармацевтичний університет Міністерства охорони здоров’я України. E-mail: elena.mozgovaya25@gmail.com. ORCID: https://orcid.org/0000-0002-6460-6816 Сведения об авторах:

Мамина Е. А., доктор фарм. наук, профессор кафедры неорганической и физической химии, Национальный фармацевтический университет Министерства здравоохранения Украины. E-mail: a_mamina@ukr.net. ORCID: http://orcid.org/0000-0001-6673-1488 Кабачный В. И., доктор фарм. наук, профессор кафедры неорганической и физической химии, Национальный фармацевтический университет Министерства здравоохранения Украины. E-mail: vikpharm@gmail.com. ORCID: http:// orcid.org/0000-0001-8620-2225 Бондаренко Н. Ю., кандидат фарм. наук, доцент кафедры неорганической и физической химии, Национальный фармацевтический университет Министерства здравоохранения Украины. E-mail: tropikana@ ukr.net. ORCID: https://orcid.org/0000-0003-0620-2255 Мозговая Е. А. кандидат фарм. наук, доцент кафедры неорганической и физической химии, Национальный фармацевтический университет Министерства здравоохранения Украины. E-mail: elena.mozgovaya25@gmail.com. ORCID https://orcid.org/0000-0002-6460-6816

Надійшла до редакції 04.12.2020 р. 